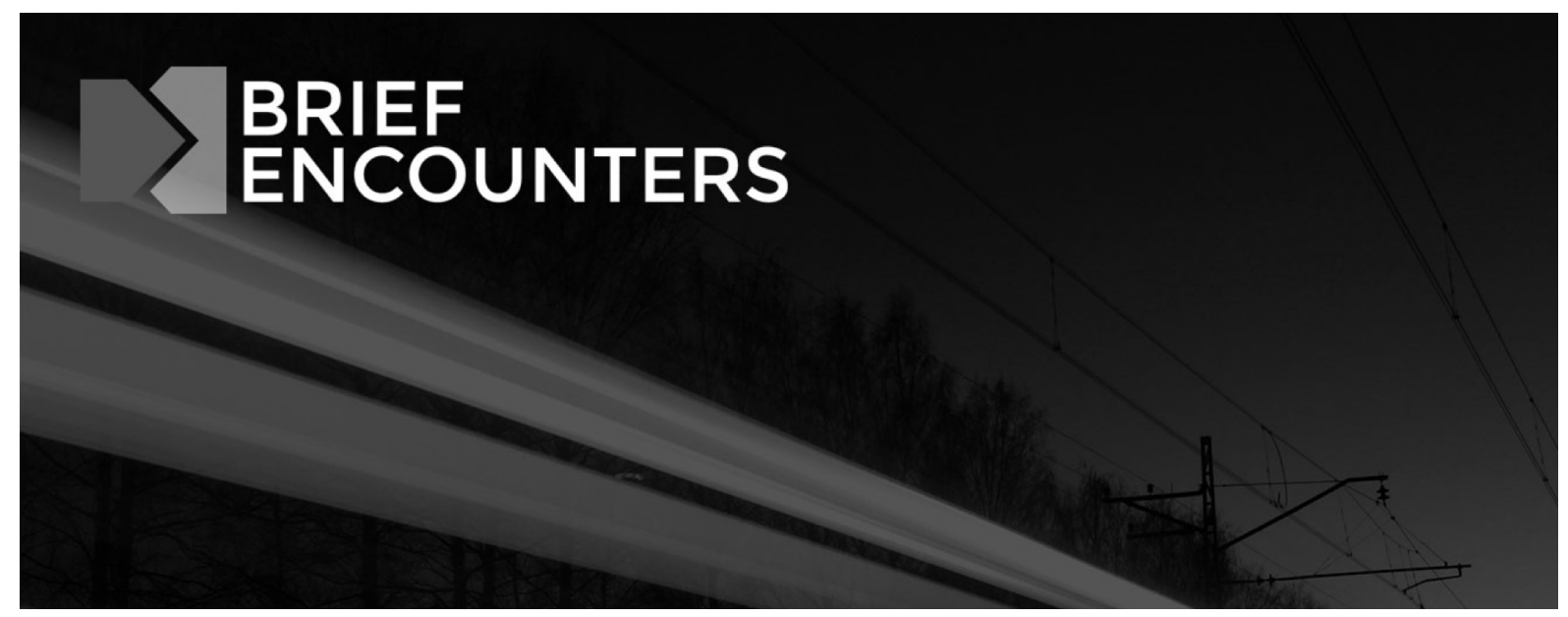

ISSN 2514-0612

Journal homepage: http://briefencounters-journal.co.uk/BE

Empathising with Bog Bodies: Seamus Heaney and the Feminine Sublime

Author(s): Patrick Wright

Email: patrick.wright@open.ac.uk

Source: Brief Encounters Vol.1, No. 1 (Feb 2017)

URL: http://briefencounters-journal.co.uk/BE/article/view/19/

DOI: http://dx.doi.org/10.24134/be.v1i1.19

(C) Patrick Wright, 2017

License (open-access): This is an open-access article distributed under the terms of the Creative Commons Attribution License 4.0, which permits unrestricted use, distribution, and reproduction in any medium, provided the original work is properly cited. No warranty, express or implied, is given. Nor is any representation made that the contents will be complete or accurate or up to date. The publisher shall not be liable for any actions, claims, proceedings, demand or costs or damages whatsoever or howsoever caused arising directly or indirectly in connection with or arising out of the use of this material.

Brief Encounters is an open access journal that supports the dissemination of knowledge to a global readership. All articles are free to read and accessible to all with no registration required. For more information please visit our journal homepage: http://briefencounters-journal.co.uk/BE. 


\section{Empathising with Bog Bodies: \\ Seamus Heaney and the Feminine Sublime}

\section{Patrick Wright}

Here I would like to propose that Seamus Heaney's bog poems, in his collection North, represent the body in such a way as to evoke the sublime. In depicting bodies in the way he does, Heaney presents them as an unusual conflation of terror and beauty, which is, I will claim, his precise articulation of the sublime - one that is distinct from the sublime presented by Edmund Burke and Immanuel Kant. In recognition of the fact that much of the scholarly writing on North, thus far, has focused its attention on how these poems convey Heaney's Irishness, his relationship to politics and the Troubles, his mythopoeic imagination and so on, my aim here is to advance the critical discourse on his work, and to move the analysis towards feminist commentary and the affective dimension of the poems. In part, this article looks to address Heaney's poems through a feminist lens rather than add to the number of historicist approaches which have been enacted to date. ${ }^{1}$ With this in mind, I will engage with a feminist critique of Heaney, which, though nuanced, often sees him as representative of an ogre-like patriarchy. Though some of the scholarship I respond to here is not necessarily recent, such as Patricia Coughlan's work, its influence continues to be felt; as such I would like to counter the accusation that Heaney's aesthetic is exploitative of its object. In order to do this, I will draw upon the concept of the feminine sublime, which has been developed by critics such as Joanna Zylinska and, more recently, by myself.2 To put it simply,

\footnotetext{
${ }^{1}$ See Ciaran Carson's attack on Heaney as a 'laureate of violence': Ciaran Carson, 'Escaped from the Massacre?', Honest Ulsterman, 50 (1975), 183-186.

2 See Joanna Zylinska, Spiders, Cyborgs and Being Scared: The Feminine and the Sublime (Manchester: Manchester University Press, 2001); Barbara Freeman, The Feminine Sublime: Gender and Excess in Women's Fiction (Berkeley: University of California Press, 1995); Patricia Yaeger, 'Toward a Female Sublime', in Gender and Theory: Dialogues in Feminist Criticism, ed. by Linda Kauffman (Oxford: Blackwell, 1989), pp. 191-212; Patrick Wright, 'A Timeless Sublime?: Reading the Feminine Sublime in the Discourse of the Sacred', Angelaki: Journal of the Theoretical Humanities, 15.2 (August, 2010), 85-100 <https://doi.org/10.1080/0969725X.2010.521393> [accessed 21 October 2016].
} 
this mode of the sublime, rather than give rise to the aggrandisement of the subject, remains in an open dialogue with the feminine - in Heaney's case the bog and the bodies it contains. Here the feminine consists of the bodies Heaney writes about (as subjects in their own right) and the mother's body which, in psychoanalytic theory, needs to be segregated, or, most aptly in relation to the bog victims, sacrificed for the sake of subjectivity.

The tendency to read Heaney's North in terms of place and time - more specifically, the politics of Ireland - and in terms of myth, has, I believe, occluded other possible readings, such as reading it through the lens of the sublime. A too easy linkage of the bog poems in this collection with political violence and with English colonialism is, I suggest, well-trodden ground. I proceed on the premise that Heaney's poems remain irreducible to their historical milieu. Perhaps it is banal to admit that, yes, North is of its time, and the commentaries that labour this point, such as Edna Longley's, certainly have their merits. ${ }^{3}$ Such readings, though, usually begin by raising the rationale for producing the poems to a highly sublimated level (an example being found in the Troubles), while the more primary dynamic of the sublime - the original trauma induced by the image and its transposition into words - is evaded. ${ }^{4}$

I do not wish to contest Longley's reading other than to make the obvious point that, in remaining at the level of politics and neglecting the role of the psyche in the process, it is highly reductive. ${ }^{5}$ To excavate further, it is necessary to trace the metaphorical axis of the bog to the very source of the sublime. One place to begin this endeavour, as one might expect with the sublime, is with Heaney's initial visual encounter with P. V. Glob's The Bog People. ${ }^{6}$ Here, a book that Heaney read immediately prior to his bog series in North, vision serves as

\footnotetext{
3 See Edna Longley, "Inner Emigré" or "Artful Voyeur"? Seamus Heaney's North', in Poetry in the Wars (Newcastle upon Tyne: Bloodaxe Books, 1986), pp. 140-169.

${ }^{4}$ One of the few precedents for this approach that features Heaney's work is Hamish Canham's Acquainted with the Night: Psychoanalysis and the Poetic Imagination (London: Karnac Books, 2003).

5 Such reductiveness is also evident in David Lloyd's "Pap for the Dispossessed": Seamus Heaney and the Poetics of Identity', Boundary 2, 13.2/3 (Winter-Spring, 1985), 319-342; Carlanda Green's 'The Feminine Principle in Seamus Heaney's Poetry', in Critical Essays on Seamus Heaney, ed. by Robert F. Garratt (New York: G.K. Hall \& Co., 1995), 151-158; and Andrew Foley's "'Befitting Emblems of Adversity": The Bog Poems of Seamus Heaney', English Studies in Africa, 41.1 (1998), 61-71 <https:// doi.org/10.1080/00138399808691267> [accessed 21 October 2016].

6 P. V. Glob, The Bog People: Iron-Age Man Preserved, trans. by Rupert Bruce-Mitford (London: Faber \& Faber, 1969).
} 
the catalyst. As is usually the case with the sublime, Heaney partakes in an interplay of image and word, where these poems might be read, as Andrew Miller contends, as 'suppressed ekphrases'.7 This understanding is supported by Heaney himself in 'Feelings into Words', an essay he wrote about the composition of the poems, his ekphrastic dialogue at its most overt in 'The Grauballe Man'.8 While North captures Heaney's fascination with the themes in Glob's book - most notably the practice of human sacrifice - these poems arise, essentially, from the horror of its images.

Indeed, in most definitions of the sublime vision is the privileged sense, and what is visualised usually leads to a surplus of sensation which both attracts and repels the viewer. In terms of its psychodynamics, the sublime begins with what Julia Kristeva refers to as the abject. The abject is that which poses a risk to the boundaries of identity, such as filth, waste or cadavers. Bodies especially threaten the self and civilisation, and so must be expelled to the outskirts of society. Appropriately, in the context of Glob, this function is also related to sacrifice; casting out from a community whatever places it at risk, and in so doing rendering such things sacred. The corpses in Glob's book are evocative of the abject, 'the place where meaning collapses', but it is Heaney's poetic response that can be argued as sublime. ${ }^{9}$ And it is a sublime where he identifies with (rather than re-inters) the sacrificial victim.

For Kristeva the abject is 'edged with the sublime', and even if 'not the same moment on the journey' the 'same speech bring[s] them into being.' ${ }^{10}$ The sublime is often seen, if not in terms of the abject, as an initial threat to the subject, and this is then surmounted in a way that brings about self-mastery. Burke associates the sublime with a feeling of terror: 'an idea belonging to self-preservation [...] one of the most affecting we have.' For him 'its strongest

\footnotetext{
${ }^{7}$ Andrew D. Miller, Poetry, Photography, Ekphrasis (Liverpool: Liverpool University Press, 2015), p. 121.

${ }^{8}$ Seamus Heaney, 'Feelings into Words', in Preoccupations: Selected Prose, 1968-1978 (London: Faber \& Faber, 1980), pp. 41-60. 9 Julia Kristeva, Powers of Horror: An Essay on Abjection, trans. by Leon S. Roudiez (New York: Columbia University Press, 1982), p. 2.

10 Ibid., p. 2, pp. 11-12. John Goodby supports this reading of Heaney's bog in Irish Poetry Since 1950: From Stillness into History (Manchester: Manchester University Press, 2000), p. 163.
} 
emotion is [...] distress', and 'no pleasure from a positive cause belongs to it.' ${ }^{11}$ His sublime is kept in opposition to beauty, which is, in effect, the feminine domesticated. For Kant the sublime is 'an abyss in which the imagination is afraid to lose itself', and the subject must employ reason in order to repossess its autonomous dimension. ${ }^{12}$ However, as Zylinska notes, this 'capitalisation of excess' tames and annuls the feminine, producing an aesthetic which precludes an ethical relationship with the other. In response, Zylinska furthers the idea of a feminine sublime, which rather than 'domesticate the object that might be a source of threat [...] accepts the relationship of both pleasure and pain, or life and death, and the potential dispersal of the self.' ${ }^{13}$ Such a sublime would also invite a more enduring relationship with the feminine, one which brings about empathy and recognises that the other is always and already in the psyche. It seems that Heaney, in bringing sacrificed victims to the surface, in conferring them with humanity and dignity, practices a version of what Zylinska theorises.

As is evident in the poems in North, Heaney, a self-declared 'child of Romanticism', is concerned with the horrors and the wonders of Nature. ${ }^{14}$ He writes, for instance, of 'the smells of waterweed, fungus and dank moss' ('Personal Helicon')15. Heaney consistently alludes to the earth, abjection, and by extension the very seedbed of the sublime - mud, mould, silt, slime, slicks - all of which become aestheticised in the process of composition. ${ }^{16}$ The sublime, in other words, has its roots in all that is base and formless. Heaney's bog, a muse, is a terrifying abyss: 'As a child I used to imagine my helpless body whistling down a black shaft forever and ever'.17 There is a sexual connotation in his perception of 'the

\footnotetext{
${ }^{11}$ Edmund Burke, A Philosophical Enquiry into the Origin of Our Ideas of the Sublime and the Beautiful (London: Dodsley, 1767), p. 79.

12 Immanuel Kant, The Critique of Judgment, trans. by James Meredith (Oxford: Clarendon, 1952), p. 107.

13 Zylinska, p. 12, p. 31.

${ }^{14}$ Seamus Heaney, in George Morgan, 'Interview with Seamus Heaney', Cycnos, 15.2 (July, 2008; orig. March, 1998) <http:// revel.unice.fr/cycnos/index.html?id=1594> [accessed 21 October 2016].

${ }^{15}$ Seamus Heaney, 'Personal Helicon', in Death of a Naturalist (London: Faber \& Faber, 1966), p. 38.

${ }^{16}$ See Seamus Deane, 'Powers of Earth and Visions of Air', in Seamus Heaney: The Shaping Spirit, ed. by C. Mallow and P. Carey (Newark: University of Delaware Press, 1996), pp. 27-33.

${ }^{17}$ Edward Broadbridge, Seamus Heaney (Copenhagen: Danmarks Radio, 1977), p. 17.
} 
moistness, the softness of the bog, its fecundity, its femininity.' ${ }^{18}$ Moreover, in his bog poems the bog is presented as female, overwhelming and dangerous: 'she tightened her torc on him'. ${ }^{19}$ The bodies in North are frequently eroticised where, as Henry Hart asserts, 'death, sex, and a gruesome fusion of the two find a new and startling expression'.20 On this point, comparable with Yeats, Heaney is preoccupied with sex and death, and shares Crazy Jane's insight that 'fair and foul are near of kin / And fair needs foul'. ${ }^{21}$ Distinct, then, from Burke and Kant's subjugation of the feminine, Heaney's aesthetic, his precise mode of sublimation, is closer to that of Yeats, who likewise sought to reconcile the beautiful and the sublime. ${ }^{22}$

Looking, first, at the images presented in Glob's book, the Grauballe Man is shocking and produces a visceral sense of disgust. This is the abject moment; all else, thinking, writing, aestheticising, are the means by which subjectivity is recovered. With reference to the Kantian sublime, the 'negative pleasure' one might experience here is first registered through vision, and is felt in the body. ${ }^{23}$ Though it is fair to say that the image of a murdered corpse buried and unintentionally preserved for millennia - might smack of something political for Heaney and his readers at the time of publication, this thought comes later. As Charles Armstrong confirms, Heaney's poems begin not with thinking in terms of political generalities, they begin with an individual sensual encounter, one which his aesthetic seeks to transcend. ${ }^{24}$ This is in keeping with the Romantic tradition that Heaney belongs to, even though his

\footnotetext{
${ }^{18}$ Michael Parker, Seamus Heaney: The Making of the Poet (London: Macmillan, 1993), p. 87.

${ }^{19}$ Seamus Heaney, 'The Tollund Man', in Wintering Out (London: Faber \& Faber, 1972), pp. 47-48. Moynagh Sullivan argues likewise in 'The Treachery of Wetness', Irish Studies Review, 13.4 (2005), 451-468 <https://doi.org/ 10.1080/09670880500304527> [accessed 21 October 2016].

20 Henry Hart, 'History, Myth, and Apocalypse in Seamus Heaney's North', Contemporary Literature, 30.3 (Autumn, 1989), 387-411 <https://doi.org/10.2307/1208411> [accessed 21 October 2016] (p. 387).

21 ' I am still of the opinion that only two topics can be of the least interest to a serious and studious mind - sex and the dead'. William Butler Yeats, The Letters of William Butler Yeats, ed. by Allan Wade (New York: Macmillan, 1954), p. 730. See also William Butler Yeats, 'Crazy Jane talks with the Bishop', in Selected Poems (London: Penguin Books, 2000), p. 183.

22 On the Yeatsian aesthetic see Jefferson Holdridge, Those Mingled Seas: The Poetry of W.B. Yeats, the Beautiful and the Sublime (Dublin: University College Dublin Press, 2000), p. 4. On the Irish sublime, see Terry Eagleton, 'Aesthetics and Politics in Edmund Burke', History Workshop Journal, 28.1 (1989), 53-62 <https://doi.org/10.1093/hwj/28.1.53> [accessed 21 October 2016]; Terry Eagleton, 'The Irish Sublime', Religion \& Literature, 28.2/3 (Summer/Autumn, 1996), 25-32.

${ }^{23}$ On the sublime defined as 'negative pleasure', see Immanuel Kant, The Critique of Judgement, trans. by James Meredith (Oxford: Clarendon, 1952; orig. 1790), Section 23.

${ }^{24}$ See Charles I. Armstrong, 'Touch and Go: Seamus Heaney and the Transcendence of the Aesthetic', in The Body and Desire in Contemporary Irish Poetry, ed. by Irene Gilsenan Nordin (Dublin: Irish Academic Press, 2006), pp. 213-225.
} 
sublime, as I will clarify, can be distinguished in that he continues to look at the body of horror. When one has finally finished digging in Heaney's bog, excavating what has been repressed in the process of metaphorising, one is hit with the most traumatising image, 'The first picture of the Grauballe man'. 25 Have you seen it? Look again, please.

After this, the sight of the corpse, Heaney's poems involve layering metaphors over the fearful bog, by which he produces the sublime. The 'basalt egg', the 'purse of a mussel', the chin 'a visor', each excavate and, in turn, aestheticise the grim discovery of putrid flesh. ${ }^{26}$ Excavation, in fact, is a key image in both Heaney's poems and the discourse of the sublime. As the etymology (from the Latin, sub, 'under' or 'up to', and limen, 'threshold') implies, the sublime and these poems operate on the paradigmatic axis of metaphor. ${ }^{27}$ That is, metaphor (as in the sublime) works as substitution, placing one strata of meaning on or over another image, and in so doing the subject is transformed. With reference to 'The Grauballe Man', Longley notes these psychodynamics in action, where '[b]eauty [...] has outweighed atrocity [and] the poem almost proclaims the victory of metaphor over "actuality".'.28 Almost, and not quite a victory, as might be the case in Burkean or Kantian sublimes. Indeed, while the materiality of death in Heaney's bog poems must be obscured, with metaphor serving here as a kind of imaginary sediment, these layers are thin. And Heaney's sublime remains close to the site of corporeality, never elevating or straying too far from vision, a horror he beautifies and associates with birth. For example, his line, 'bruised like a forceps baby', by no means offers us a conquering or aggrandising sublime; instead this is a sublime that starkly envisions a man 'hung in the scales / with beauty and atrocity'. ${ }^{29}$ What the Grauballe Man signifies is a terrible beauty, an overload of stimulus that defies comprehension, and thus requires the discipline of poetry to contain both

\footnotetext{
${ }^{25} \mathrm{Glob}$, 'The first picture of the Grauballe man' (plate 9), p. 38.

${ }^{26}$ Seamus Heaney, 'The Grauballe Man', in North (London: Faber \& Faber, 1975), pp. 35-36 (p. 35).

27 As McHale argues, these poems are archaeological, 'in the sense of responding directly to [...] actual archaeological discoveries.' Brian McHale, 'Archaeologies of Knowledge: Hill's Middens, Heaney's Bogs, Schwerner's Tablets', New Literary History, 30.1 (Winter, 1999), 239-262 (p. 243).

28 Longley, Poetry in the Wars, p. 152.

${ }^{29}$ Heaney, The Grauballe Man', p. 36.
} 
vision and affect within appropriate limits. Though in conceding that his Dying Gaul is 'too strictly compassed' in his art, this is clearly a mode of the sublime - a Heaneyan sublime - that remains humble enough to accept the inadequacies of representation, of death and barbarism inflicted on the body: 'each hooded victim / slashed and dumped'. ${ }^{30}$ His sublime, that is to say, admits no more can be said, and invites the reader to identify with the body:

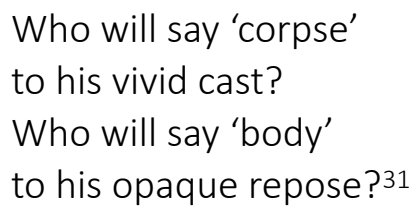

Thus Heaney's sublime is less about political might or conquering the thing of terror, rather it is about a close identification with the sacrificial victim. This proposal is best advanced by looking at his poem 'Bog Queen', where the body speaks for itself. ${ }^{32}$ This poem is not, in other words, a re-enactment of male violence as Patricia Coughlan's critique makes a case for. For Coughlan, the bog poems are comparable with the work of John Montague, insofar as each poet fails to confer the female other with autonomy. Instead, this other is presented as the ground against which the male subject is constituted - as occurs within the Burkean and Kantian sublimes. Coughlan writes:

So must we not conclude that the poetry of Montague and Heaney as a whole is insistently and damagingly gendered? Its masculine personae, whether in the narrative of personal identity, or that of nationality, must, it seems, possess or be possessed by a counter-force personified as feminine: an encounter of the genders as of aliens - dog eat dog, possess or be swallowed up - is forever occurring, even within and beneath politics. ${ }^{33}$

\footnotetext{
30 Ibid., p. 36.

${ }^{31}$ Ibid., p. 36. This stance in relation to the suffering body is supported by Jennifer Wallace, "'We Can't Make More Dirt...": Tragedy and the Excavated Body', The Cambridge Quarterly, 32.2 (2003), 103-11 <https://doi.org/10.1093/camqtly/ 32.2.103> [accessed 21 October 2016].

32 Seamus Heaney, 'Bog Queen', in North (London: Faber \& Faber, 1975), pp. 32-34.

33 Patricia Coughlan, "Bog Queens": The Representation of Women in the Poetry of John Montague and Seamus Heaney' in Theorizing Ireland, ed. by Claire Connolly (Basingstoke: Palgrave Macmillan, 2003), pp. 41-60; see also Nathalie F. Anderson, 'Queasy Proximity: Seamus Heaney's Mythical Method', in Critical Essays on Seamus Heaney, ed. by Robert F. Garratt (New York: G.K. Hall \& Co., 1995), pp. 139-150.
} 
Coughlan is fair, I think, in her view that Heaney's bog poems are emblematic of the magna mater, or Great Mother archetype discussed in Jung's psychoanalysis - the giver of life and death, a figure connected with the body of the earth, the unconscious and affect. This is evinced by Heaney's idea of writing as 'a kind of somnambulist encounter between masculine will and intelligence and feminine clusters of image and emotion'.34 Nevertheless, even though Heaney is culpable of some binary thinking - the dichotomies of male and female, light and dark as well as intellect and emotion - I do not see Heaney's engagement with the feminine in terms of exploitation with its source in masculinist fear, as Coughlan does. Instead, closer to Carlanda Green's more sympathetic reading, Heaney's bog poems might be more accurately read as working, dialectically, towards an identification with the feminine. ${ }^{35}$ That is to say, even though there is some essentialising of the sexes at work in these poems, 'Bog Queen' problematises this dualism in and through its deployment.

Looking now at 'Bog Queen', one can see that Heaney writes in the first person ('I lay waiting') and implies there is a dialogue between the body and the land ('My body was braille / for the creeping influences'). ${ }^{36}$ He gives her body a voice; though this voice remains his own. This is comparable to Yeats's 'Crazy Jane' poems, where Yeats also constructs a female persona to articulate risqué sentiments that he could, instead, take ownership for. It might be suggested that such a voice talks over the feminine; though I prefer to see this relationship in terms of the interdependence of opposites, which, rather than negate, invites the embodiment of sensuality and a positive identification with the feminine. Creating and voicing female speakers as they do, these male poets recognise the strangeness of the other within, that qualities often codified as feminine are, upon reflection, human. Given too that the Bog Queen rises 'from the dark', her status is neither

\footnotetext{
${ }^{34}$ Green, p. 151.

35 See Christine Hoff Kraemer's 'Channelling the Great Mother: Gender Dualism in Heaney's "Bog Queen”', Christine Hoff Kraemer (2003) <http://www.christinehoffkraemer.com/bogqueen.html> [accessed 21 October 2016].

36 Heaney, 'Bog Queen', p. 34.
} 
alive nor dead, she is familiar and unfamiliar. Rather than just a corpse, she is a mummy. ${ }^{37}$ Even before Heaney dramatises her uncanny reanimation, the photograph elicits a similar effect. For Roland Barthes, such pictures 'certify that the corpse is alive, as corpse: it is the living image of a dead thing.' ${ }^{38}$

The Bog Queen is not abject then since, if that were the case, she would be seen as entirely other. In Heaney's poem she inhabits more of a liminal region: at once foreign and relatable. For this reason, and consistent with Glob's theme of sacrifice, the Bog Queen can also be seen as a scapegoat - situated between the sacred and profane, sickness and health, weakness and strength, inside and outside. As Terry Eagleton affirms, the scapegoat 'is a substitute for the people, and thus stands in a metaphorical relationship to them; but it also acts as a displacement for their sins, and is in that sense metonymic.' What seems crucial in the context of the feminine sublime is that rather than abject the female other, which might allow Heaney to purge the violence inflicted on the Bog Queen, and thus reestablish some distance and ascendency, she is pitied. This is not, in other words, a poem which represents horror of the body but rather the social order whose failure it marks. The body, likewise, is presented as a judgement on that order in its very being. Thus the scapegoat,

bears the seeds of revolutionary agency in its sheer passivity; for anything still active and engaged, however dissidently, would still be complicit with the polis, speaking its language and thus unable to put it into question as a whole. Only the silence of the scapegoat will do this. ${ }^{39}$

In support of this notion is a thesis offered by Eugene O'Brien, who, rather than following the more orthodox appraisal of North as justifying or glorifying violence, uses its poems to indicate how the ethical works within Heaney's aesthetic, since the bog bodies especially are shown as frail, wounded and vulnerable, and ultimately to be identified with rather than

\footnotetext{
37 Ibid., p. 34.

38 Roland Barthes, Camera Lucida, trans. by Richard Howard (London: Vintage, 1993), pp. 78-79.

39 Terry Eagleton, Sweet Violence: The Idea of the Tragic (Oxford: Blackwell, 2003), p. 279.
} 
abjected. ${ }^{40}$ This identification is confirmed by Heaney's suggestion in the poem that the woman is not simply dead; she is becoming, birthing herself as 'a jar of spawn / fermenting underground / dreams of Baltic amber.'41 She's 'hibernated', not dead, and the plait of her hair is 'a slimy birth-cord'.42 Not just death-bearing then, as Dillon Johnston suggests; the female body is also a sign of life. ${ }^{43}$

As my thesis demonstrates, reading Heaney's bog poems in terms of the ethics of sacrifice dovetails rather well with the feminine sublime. Both are concerned with recognising otherness in the encounter, risking the possibility of empathy rather than sublimation for the sake of catharsis or the shoring up of subjective bounds. Likewise, seeing the poems through Glob's pictures - reinstating the prominence of the visual in the poems' inception - lends weight to the idea that Heaney maintains his gaze, mediates in effect the abjection that other proponents of the sublime might more swiftly turn away from. That is to say Heaney, for me, embodies a sublime which relates with female subjectivity while cognisant that the abject is at the core of his own psyche. Though his metaphors enact some degree of sublimation (due, most likely, to fearing too close a relationship with death and the mother's body), Heaney is by no means misogynistic; instead, through an ongoing dialogue, one which risks the self to the other (though not at the risk of life itself), his poems share in the sufferings of the victim.

\footnotetext{
40 Eugene O'Brien, 'The Body as Ethical Synecdoche in the Writing of Seamus Heaney', in The Body and Desire in Contemporary Irish Poetry, ed. by Irene Gilsenan Nordin (Dublin: Irish Academic Press, 2006), pp. 79-100.

${ }^{41}$ Heaney, 'Bog Queen', p. 32-33.

42 Ibid., p. 33, p. 34.

${ }^{43}$ See Dillon Johnston, 'Irish Poetry After Joyce (Heaney and Kavanagh)', in Critical Essays on Seamus Heaney, ed. by Robert F. Garratt (New York: G.K. Hall \& Co., 1995), pp. 121-166.
} 


\section{Bibliography}

Anderson, Nathalie F., 'Queasy Proximity: Seamus Heaney's Mythical Method', in Critical Essays on Seamus Heaney, ed. by Robert F. Garratt (New York: G.K. Hall \& Co., 1995), pp. $139-150$

Armstrong, Charles I., 'Touch and Go: Seamus Heaney and the Transcendence of the Aesthetic', in The Body and Desire in Contemporary Irish Poetry, ed. by Irene Gilsenan Nordin (Dublin: Irish Academic Press, 2006), pp. 213-225

Barthes, Roland, Camera Lucida, trans. by Richard Howard (London: Vintage, 1993)

Broadbridge, Edward, Seamus Heaney (Copenhagen: Danmarks Radio, 1977)

Burke, Edmund, A Philosophical Enquiry into the Origin of Our Ideas of the Sublime and the Beautiful (London: Dodsley, 1767)

- Reflections on the Revolution in France (London: Penguin Classics, 1986)

Canham, Hamish, Acquainted with the Night: Psychoanalysis and the Poetic Imagination (London: Karnac Books, 2003)

Carson, Ciaran, 'Escaped from the Massacre?', Honest Ulsterman, 50 (1975), 183-186 Coughlan, Patricia, "'Bog Queens": The Representation of Women in the Poetry of John Montague and Seamus Heaney', in Theorizing Ireland, ed. by Claire Connolly (Basingstoke: Palgrave Macmillan, 2003), pp. 41-60

Deane, Seamus, 'Powers of Earth and Visions of Air', in Seamus Heaney: The Shaping Spirit, ed. by C. Mallow and P. Carey (Newark: University of Delaware Press, 1996), pp. 27-33 Eagleton, Terry, 'Aesthetics and Politics in Edmund Burke', History Workshop Journal 28.1 (1989), 53-62 <https://doi.org/10.1093/hwj/28.1.53> [accessed 21 October 2016]

- Sweet Violence: The Idea of the Tragic (Oxford: Blackwell, 2003) 
__ 'The Irish Sublime', Religion \& Literature, 28.2/3 (Summer/Autumn, 1996), 25-32

Foley, Andrew, "'Befitting Emblems of Adversity": The Bog Poems of Seamus Heaney', English Studies in Africa, 41.1 (1998), 61-71 <https://doi.org/10.1080/00138399808691267> [accessed 21 October 2016]

Freeman, Barbara, The Feminine Sublime: Gender and Excess in Women's Fiction (Berkeley: University of California Press, 1995)

Glob, P. V., The Bog People: Iron-Age Man Preserved, trans. by Rupert Bruce-Mitford (London: Faber \& Faber, 1969)

Goodby, John, Irish Poetry Since 1950: From Stillness into History (Manchester: Manchester University Press, 2000)

Green, Carlanda, 'The Feminine Principle in Seamus Heaney's Poetry', in Critical Essays on Seamus Heaney, ed. by Robert F. Garratt (New York: G.K. Hall \& Co., 1995), pp. $151-158$

Hart, Henry, 'History, Myth, and Apocalypse in Seamus Heaney's North', Contemporary Literature, 30.3 (Autumn, 1989), 387-411 <https://doi.org/10.2307/1208411> [accessed 21 October 2016]

Heaney, Seamus, Death of a Naturalist (London: Faber \& Faber, 1966)

— North (London: Faber \& Faber, 1975)

Wintering Out (London: Faber \& Faber, 1972)

_. 'Feelings into Words', in Preoccupations: Selected Prose, 1968-1978 (London: Faber \& Faber, 1980), pp. 41-60

Holdridge, Jefferson, Those Mingled Seas: The Poetry of W.B. Yeats, the Beautiful and the Sublime (Dublin: University College Dublin Press, 2000) Hufstader, Jonathan, "Coming to Consciousness by Jumping in Graves": Heaney's Bog Poems and the Politics of "North", Irish University Review, 26.1 (Spring-Summer, 1996), 61-74 
Johnston, Dillon, 'Irish Poetry After Joyce (Heaney and Kavanagh)', in Critical Essays on Seamus Heaney, ed. by Robert F. Garratt (New York: G.K. Hall \& Co., 1995), pp. 121-166

Kant, Immanuel, The Critique of Judgement, trans. by James Meredith (Oxford: Clarendon, 1952)

Kraemer, Christine Hoff, 'Channelling the Great Mother: Gender Dualism in Heaney's "Bog Queen"', Christine Hoff Kraemer (2003) <http://www.christinehoffkraemer.com/ bogqueen.html> [accessed 21 October 2016]

Kristeva, Julia, Powers of Horror: An Essay on Abjection, trans. by Leon S. Roudiez (New York: Columbia University Press, 1982)

Lloyd, David, "'Pap for the Dispossessed”: Seamus Heaney and the Poetics of Identity', Boundary 2, 13.2/3 (Winter-Spring, 1985), 319-342

Longley, Edna, Poetry in the Wars (Newcastle upon Tyne: Bloodaxe Books: 1986)

McCarthy, Conor, Seamus Heaney and Medieval Poetry (Cambridge: D.S. Brewer, 2009) McHale, Brian, 'Archaeologies of Knowledge: Hill's Middens, Heaney's Bogs, Schwerner's Tablets', New Literary History, 30.1 (Winter, 1999), 239-262

Meredith, Dianne, 'Landscape or Mindscape? Seamus Heaney's Bogs', Irish Geography, 32.2 (1999), 126-34 <https://doi.org/10.1080/00750779909478606> [accessed 21 October 2016]

Miller, Andrew D., Poetry, Photography, Ekphrasis (Liverpool: Liverpool University Press, 2015) Morgan, George, 'Interview with Seamus Heaney', Cycnos, 15.2 (July, 2008; orig. March, 1998) <http://revel.unice.fr/cycnos/index.html?id=1594> [accessed 21 October 2016] O'Brien, Eugene, 'The Body as Ethical Synecdoche in the Writing of Seamus Heaney', in The Body and Desire in Contemporary Irish Poetry, ed. by Irene Gilsenan Nordin (Dublin: Irish Academic Press, 2006), pp. 79-100

Parker, Michael, Seamus Heaney: The Making of the Poet (London: Macmillan, 1993) 
Sullivan, Moynagh, 'The Treachery of Wetness', Irish Studies Review, 13.4 (2005), 451-468 <https://doi.org/10.1080/09670880500304527> [accessed 21 October 2016] Wallace, Jennifer, "'We Can't Make More Dirt...": Tragedy and the Excavated Body', The Cambridge Quarterly, 32.2 (2003), 103-111 <https://doi.org/10.1093/camqtly/ 32.2.103> [accessed 21 October 2016]

Wright, Patrick, 'A Timeless Sublime: Reading the Feminine Sublime in the Discourse of the Sacred', Angelaki: Journal of the Theoretical Humanities, 15.2 (August, 2010), 85-100 <https://doi.org/10.1080/0969725X.2010.521393> [accessed 21 October 2016]

Yaeger, Patricia, 'Toward a Female Sublime', in Gender and Theory: Dialogues in Feminist Criticism, ed. by Linda Kauffman (Oxford: Blackwell, 1989), pp. 191-212

Yeats, William Butler, The Letters of William Butler Yeats, ed. by Allan Wade (New York: Macmillan, 1954)

— Selected Poems (London: Penguin, 2000)

Zylinska, Joanna, Spiders, Cyborgs and Being Scared: The Feminine and the Sublime (Manchester: Manchester University Press, 2001) 